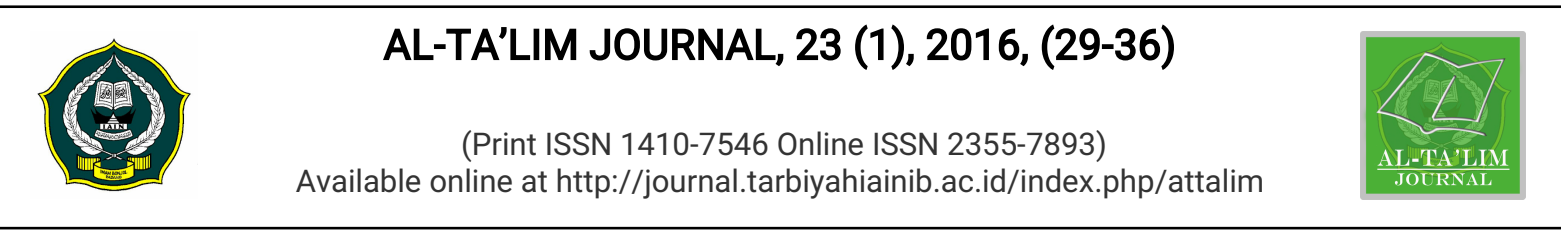

\title{
Involving Students' Opinion in Actual and Preferred Teacher Interpersonal Behavior and Their Attitude Towards Science Subject
}

\author{
Mustafa Kamal Nasution \\ Department of Tarbiyah at STAIN Gajah Putih Takengon, Aceh, Indonesia \\ Email: kamalnasution@gmail.com
}

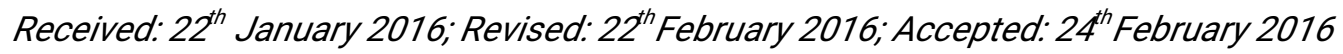

\begin{abstract}
This study aims to investigate the student perception on teacher interpersonal behavior and their attitude toward science subject. 207 respondents were involved, consisted of 200 students in 1012 grade and 7 science teachers of public high school in Aceh. Two types of questionnaires were used namely the Indonesian version of the questionnaire of teacher interaction (QTI) and test of science related attitude (TOSRA). SPSS program were applied to process the data statistically. First, the reliability of questionnaires is measured using descriptive statistics of all and each scale of QTI. Second, the difference between students' perceptions on the actual and ideal teacher interpersonal behavior was computed by Paired Sample t-tests. Third, the relationship between students' perception on teachers' interpersonal behavior and students' attitudes towards science subjects was compared using multiple regression analysis-standardized regression coefficient $\beta$. The finding showed that the Indonesian version of questionnaire of teacher interaction (QTI) is reliable ( $\mathrm{aC}=0.86)$, to be applied to the high school students in the regency. It is generally seen that the students consider their teachers demonstrate more positive interpersonal behavior than the negative. However, it is clearly seen that between actual and ideal perceptions on the whole scale of QTI is significantly different. Last, from the three scales of teacher interpersonal behavior, helping/friendly, dissatisfaction, and admonishing appeared influential, only the helping/friendly scale significantly correlate (at the .05 level) with student attitudes toward science subject.
\end{abstract}

Key Words: Teacher interpersonal behavior, high school

How to Cite: Nasution, M. (2016). Involving Students' Opinion on Actual and Preferred Teachers' Interpersonal Behavior and Their Attitude towards Science Subject. Al-Ta Lim Journal, 23(1).

doi: http://dx.doi.org/10.15548/jt.v23i1.171

Permalink/DOl:http://dx.doi.org/10.15548/jt.v23i1.171

\section{INTRODUCTION}

Teachers could just teach with "closed eyes" in their classes, spend much time and effort, to improve and, afterward, evaluate mostly on student academic achievement. However, student spends up to thousands of hour at school by the time they complete at high school. 
Teacher and researcher in education should not ignore their perception to get a complete picture of educational practice. Involving student respond and opinion are considerable (Fraser, 1998).

This study engages student perception on teacher interpersonal relationship and their attitude. Interpersonal relationships in the field of education has been defined as wide range relationships that exists between all parties involved in education such as, among students in class, teachers and teachers, school leaders, and teachers and parents (Zandvliet et al, 2014). In this study, the relationship is focused on teachers and students only. Martin (2014) revealed the importance of interpersonal relationships established between teacher and pupil. Other than parents/caregivers and peers, relationship with teachers is one of the most influential source of relationship which influences the students' academic and non-academic lives. A positive relationship between them, can also contribute positively to the academic development of students, such as outcomes (Brok et al, 2004; Goh, \& Fraser, 1998; Soerjaningsih, 2001), motivation (Maulana et al, 2010), and their attitudes toward certain subjects (Brok et al, 2005; Wahyudi, 2010). Conversely, a negative relationship among them can also adversely impact the students, and even influence their non-academic development, such as emotional condition, the personality of the student (Martin et al, 2014). Teachers who establish positive interpersonal relationships with students will generate adequate satisfaction in learning (BenChaim \& Zoller, 2001), and later, strong link to their academic achievement (Brok et al, 2004).

In recent decades, research in the field of Interpersonal Behavior undergoes significant diversification and internationalization (Fraser, 2002). Some studies intended to obtain crossvalidation (Khalili, 2006) and others improve the concept conducted in many countries such as the Netherlands (Brekelmans, Wubbels, \& Creton, 1990), Australia (Evans, 1998), Brunei (Brok, Fisher, \& Scott (2005), Singapore (Goh \& Fraser, 1998), Korea (Lee, Fraser, \& Fisher, 2003). The International Conference on Interpersonal Relationships in Education (ICRE) indicated that the teacher interpersonal behavior has become an international issue and confirmed the importance of this field to be studied deeper.

In Indonesia, research in the field of interpersonal behavior has not received great attention by researchers (Wahyudi \& Treagust, 2004). Maulana et al (2010), Soerjaningsih (2001), and Wahyudi (2010) have provided a general perspective on contemporary understanding in Indonesia. However, research in specific location, ethnic, and geographic, might contribute different or distinct perspectives and provide a meaningful comparison concept; which may only occur in that area alone. Brok and Levy (2006) added that in the research field of interpersonal relations in the future, it is possible to develop interest in the background of ethnic diversity (students 'and teachers' ethnic background) because ethnicity is very influential on the formation of student perception or teacher.

This study was conducted to assess the correlation between teacher interpersonal behaviors and students' attitudes towards science subjects. Specifically, this study was designed to answer the following questions:

1. How reliable was the questioner provided?

2. How do the students view on their teacher interpersonal behavior? To 
what extent the discrepancies between actual and preferred teachers' interpersonal behavior?

3. How does the correlation between teacher interpersonal behavior and students attitudes towards science subjects?

\section{METHOD}

This research involved 207 respondents, consisted of 200 high school students in 10-12 grade and 7 science teachers of public high school, Central Aceh Regency, Indonesia. To collect the data, two types of questionnaires were used; the 40-items Indonesian version of the questionnaire teacher interaction (QTI) in eight scales applied specifically to assess students' perceptions of student-teacher interpersonal behavior. Student attitude or enjoyment was measured by eight-item test of science related attitude (TOSRA). The wording of the item in both questionnaires are translated and adjusted in such that they can be applied to high school student in local context.

SPSS program were applied to process the data statistically. First, descriptive statistic was used on actual and preferred of each scale to estimate the QTI reliability; if it showed more than 0.5 the reliability of Cronbach alpha is acceptable. Second, Paired Sample t-test was employed to see the discrepancies between actual and preferred teachers' interpersonal behavior. Apart of the test, the average score of each scale also presents the students view on their teacher interpersonal behavior. Last, the correlation between teacher interpersonal behavior and students attitudes towards science subjects was compared using multiple regression analysis-standardized
Regression Coefficient $\beta$.

\section{RESEARCH FINDINGS AND DISCUSSION}

\section{Reliability of the Indonesian Version of QTI}

The first question raised in this study is the reliability of questionnaire given to respondents. The instrument used to measure the level of reliability in this study is Coefficient Alpha. According to Brown (2002), Cronbach Alpha Coefficients ranged from 0.00 (if there were no variants of items consistent) up to 1.00 (if all variants of items were consistent). For example, if the value of coefficient Alpha were 0.90, we can interpret that the test/questionnaire given are $90 \%$ reliable or $10 \%$ not-reliable $(100 \%$ - $90 \%=10 \%)$. Later, George and Mallery (2003:231) provide a numerical value interpretation of Cronbach Alpha as follows:

$$
\begin{array}{cl}
\quad a \geq 0.9 & \text { Excellent } \\
0.8 \leq a<0.9 & \text { Good } \\
0.6 \leq a<0.7 & \text { Acceptable } \\
0.5 \leq a<0.6 & \text { Poor } \\
a<0.5 & \text { Unacceptable }
\end{array}
$$

Tabel 1. Cronbach alpha reliability of

\begin{tabular}{|c|c|c|}
\hline \multirow{2}{*}{ QTI SCALE } & \multicolumn{2}{|c|}{ Cronbach Alpha (aC) } \\
\hline & Actual & Preferred \\
\hline Leadership- DC & 0,62 & 0,74 \\
\hline Helping/Friendly-CD & 0,82 & 0,70 \\
\hline Understanding-CS & 0,72 & 0,78 \\
\hline Students & 0,58 & 0,58 \\
\hline $\begin{array}{l}\text { Responsibility/ } \\
\text { Freedom-SC }\end{array}$ & & \\
\hline Uncertain-SO & 0,81 & 0,86 \\
\hline
\end{tabular}
overall QTI items

\begin{tabular}{r|r}
\hline $\begin{array}{c}\text { Cronbach's } \\
\text { Alpha }\end{array}$ & $\begin{array}{c}\text { N of } \\
\text { Items }\end{array}$ \\
\hline .860 & 80 \\
\hline
\end{tabular}

Tabel 2. Cronbach alpha reliability of each QTI scale 


\begin{tabular}{lll} 
Dissatisfaction-OS & 0,78 & 0,82 \\
Admonishing-OD & 0,87 & 0,87 \\
Strict-DO & 0,65 & 0,56 \\
\hline
\end{tabular}

Based on the table, the value of Cronbach alpha reliability for the eighth scale spread between $0.56-0.87$. Although the all values are acceptable, there is one scale only slightly above the lowest threshold (0.5); Students Responsibility/Freedom scale in actual and ideal items. According to Wells and Wollack (2003:7), low value of alpha could be due to quality of the items, primarily in the item's discrimination. The items are considered discriminating if the "better" students tend to respond the item properly while the "poorer" students tend to reply inaccurately.

Other quality item that affects the value might appear in term of "concept gap", difference in the concept between the present respondents and the ideal respondent QTI constructed. For example, in Freedom and Responsibility scale there are statements:

Q.16: We can decide some things in this teacher's class

Q.17: We can influence this teacher

The local high school students sampled in this study might not be fully understand the concept of "decide in teacher class" or "influence" (because "student decision" or "influencing teacher" are something that is culturally uncommon in local concept), so the students might not understand how to response to the statement. According to Fraser (1998), QTI was initially intended for western high school students. This is what the authors' means by the difference in concept (concept gap) that may occur.

Other than each scale's reliability, the descriptive statistic also reveals the overall item value of Coefficient Alpha.
Based on the George and Mallery's classification, it can be interpreted that the reliability of the overall item of QTI is good (0.86). Therefore, in general, the Indonesian version of QTI is reliable (in good level) to be administered to the high school students in Central Aceh regency.

\section{Student Perception on Teacher Interpersonal Behavior}

Table 2. Mean, standard deviation, and $t$ value of actual and preferred teachers' interpersonal behavior

\begin{tabular}{|c|c|c|c|c|c|c|}
\hline \multirow[b]{2}{*}{$\begin{array}{l}\mathrm{N} \\
\mathrm{O}\end{array}$} & \multirow[b]{2}{*}{ Scale } & \multicolumn{2}{|c|}{ Mean } & \multicolumn{2}{|c|}{$\begin{array}{l}\text { Standard } \\
\text { Deviation }\end{array}$} & \multirow[b]{2}{*}{$\begin{array}{c}\mathrm{t} \\
\text { value }\end{array}$} \\
\hline & & $\begin{array}{l}\text { Actu } \\
\text { al }\end{array}$ & $\begin{array}{c}\text { Pref } \\
\text { erre } \\
d\end{array}$ & $\begin{array}{l}\text { Act } \\
\text { ual }\end{array}$ & $\begin{array}{l}\text { Pref } \\
\text { erre } \\
d\end{array}$ & \\
\hline 1 & Leadership & 3,00 & 3,54 & 0,49 & 0,43 & $\begin{array}{c}- \\
14,07 \\
\star *\end{array}$ \\
\hline 2 & $\begin{array}{l}\text { Helping/Fri } \\
\text { endly }\end{array}$ & 3,43 & 3,99 & 0,61 & 0,47 & $\begin{array}{c}- \\
11,70 \\
\star \star\end{array}$ \\
\hline 3 & $\begin{array}{l}\text { Understan } \\
\text { ding }\end{array}$ & 2,91 & 3,54 & 0,55 & 0,47 & $\begin{array}{c}- \\
14,11 \\
\star \star\end{array}$ \\
\hline 4 & $\begin{array}{l}\text { Students } \\
\text { Responsibi } \\
\text { lity/ } \\
\text { Freedom }\end{array}$ & 1,89 & 2,48 & 0,56 & 0,77 & $\begin{array}{c}- \\
11,24 \\
\star *\end{array}$ \\
\hline 5 & Uncertain & 1,42 & 1,27 & 0,48 & 0,71 & $\begin{array}{c}3,36^{*} \\
*\end{array}$ \\
\hline 6 & $\begin{array}{l}\text { Dissatisfac } \\
\text { tion }\end{array}$ & 1,57 & 1,25 & 0,61 & 0,47 & $\begin{array}{c}8,35^{\star} \\
*\end{array}$ \\
\hline 7 & $\begin{array}{l}\text { Admonishi } \\
\text { ng }\end{array}$ & 1,81 & 1,33 & 0,79 & 0,58 & $\begin{array}{c}7,84^{\star} \\
\star\end{array}$ \\
\hline 8 & Stricts & 2,58 & 2,42 & 0,63 & 0,58 & $\begin{array}{c}3,19 * \\
*\end{array}$ \\
\hline
\end{tabular}

Note: $* \star \quad \rho<0.01 ; * \rho<0.05 ; 0-1.4=$ poor; 1.5-2.4=fair; 2.5-3.4=good; 3.5- 4=very good. The values of mean and standard deviation on the last four scales are interpreted reversely.

Due to the second question, paired sample t-tests were used to measure the discrepancies between actual and preferred teachers' interpersonal behavior. As can be seen on the table 2 , it is generally noticed that the teachers showed more positive Interpersonal 
(scale 1 to 4 ) behavior than the negative (scale 5 to 8 , dark color).

From the positives, the teacher shows three behaviors in good level $(2.5$ to 3.4); namely Leadership (3.00 \pm 0.49$)$, Helping/Friendly $(3: 43 \pm 0.61)$, and Understanding (2.91 $\pm 0: 55)$. However, the students perceived their teachers fairly $(1.89 \pm 0.77)$ express Responsibility/ Freedom to them. Oppositely, from the negatives, the teachers less showed Uncertainty, but fairly (1.5 to 2.4 ) showed satisfaction (Dissatisfaction-OS), patience (Admonishing), and Strictness. It can be concluded that teachers of science subjects have a relatively good Interpersonal Behavior from the student's perspective.

However, the discrepancies between actual and preferred teachers' interpersonal behavior is shown at significant level $(p<0: 01)$ in $\mathrm{t}$ value. The behavior expected by students is higher than the behavior they perceived from their teacher in every QTI scale. This data infers that the students evidently are expecting better behavior from their science teachers at each of the scale.

This finding also indicates that, in the local context, the students show a common perception that their ideal science teachers should demonstrate good behavior in Leadership, Friendly, Understanding Students, and gives freedom. Instead less exhibit the opposite behavior. This result is in line with Fisher, Goh, \& Rickard (1996) who explained that if the science teacher wants to improve students' good attitudes toward the subjects, the teacher must ensure the presence of interpersonal behavior in communication in the classroom.

The Correlation between Teacher

\section{Interpersonal Behavior and Student Attitude toward Science Subject}

Using Pearson correlation analysis, Table 3 shows how the teacher interpersonal behavior - in the eighth scale of QTI - correlate (r) with the student attitudes towards Science subjects. According to Wardana (2007: 32) The correlation analysis aims to determine whether there is a relationship between two or more variables; how strong the relationship is, and how the direction or shape of the relationship between two variables (in this case eight variables of teacher Interpersonal scale and student attitudes).

Table 4. Correlation ( $r$ ) and regression ( $\beta$ ) between teacher interpersonal behavior and student attitudes toward science subjects

\begin{tabular}{clcc}
\hline & & \multicolumn{2}{c}{ Student attitude } \\
\cline { 3 - 4 } $\mathrm{N}$ & \multicolumn{1}{c}{$\begin{array}{c}\text { Teacher } \\
\mathrm{O}\end{array}$} & $\begin{array}{c}\text { Standardiz } \\
\text { ed }\end{array}$ \\
& & $\begin{array}{c}\text { Correlation } \\
(\mathrm{r})\end{array}$ & $\begin{array}{c}\text { Regression } \\
\text { Coefficient } \\
(\beta)\end{array}$ \\
\hline 1 & Leadership- DC & 0.062 & $-0,027$ \\
2 & Helping/Friendly-CD & $0,205^{\star \star}$ & $0,206^{\star}$ \\
3 & Understanding-CS & 0,007 & $-0,102$ \\
& Students & 0.005 & $-0,031$ \\
4 & Responsibility/ & & \\
& Freedom-SC & & \\
5 & Uncertain-SO & $-0,060$ & 0,147 \\
6 & Dissatisfaction-OS & $-0.161^{\star}$ & $-0,104$ \\
7 & Admonishing-OD & $-0.213^{\star \star}$ & $-0,157$ \\
8 & Strict-DO & $-0,104$ & $-0,019$ \\
\hline
\end{tabular}

Note:

* Correlation is significant at level 0,05 (2 -tailed). ** Correlation is significant at level 0,01 (2-tailed).

Correlation values range between -1 and +1 , where positive or negative values indicate the direction of correlation. The positive correlation happens if there were an increase in the value of the variable followed by the rise of other variables. Oppositely, the 
negative correlation occurs if the following variables decrease. The strength of the correlation is shown by the amount of value ranged from 0 to +1 or -1 to 0 . If the correlation value were higher than 0.5 , then both of variables are correlated strongly. Thus, a weak correlation occurs if the value were less than 0.5 (Wardana, 2007: 32).

Based on the explanation above, it can be interpreted that a positive correlation ( $r$ ) is noticed on the four top behaviors (number 1 to 4 ), and negatively correlated to the four behaviors underneath. This finding infer that the higher the behavior of leadership, friendship, understanding, and freedom, the teachers express, the better students demonstrate attitudes toward science subject. Conversely, the higher the behavior of uncertainty, dissatisfaction, admonishing, and strict, the lower students' attitudes toward science subject become. This is consistent with what proposed by Goh (1994);

Teachers who exhibited more positive behaviours (e.g., leadership and understanding behaviours) in their daily interactions with students facilitated the development of favorable attitudes and better achievement among students, while negative teacher's behaviors (e.g., uncertain and dissatisfied behaviours) produced the reverse effect.

However, from all eighth interpersonal behavior scales, there were no correlation values showing higher than 0.5 . It means that the correlation of all eighth interpersonal behavior scale and student attitudes is not strong (weak). Furthermore, although there are positive and negatives relationships of the eighth behavior scale interpersonal towards students attitude, only three (3) behaviors significantly correlated; Helping / Friendly, Dissatisfaction, and Admonishing.

Another desirable explanation from the third questions, Table 2 also provides the value regression through multiple regression analysis (standardized Regression Coefficient $\beta$ ). The analysis aims to determine which independent variables control the dependent variable significantly (Wardana, 2007: 41). The standardized Regression Coefficient provides a comparing contribution of each independent variable in explaining the variance of the dependent variable (disregard its negative mark). Whereas an asterisk $\left(^{*}\right)$ means whether a certain independent variables provide contributing / significant effect at a certain level (0.05 or 0.01) (Wardana, 2007: 47). Based on the explanation, it can be interpreted that from the three (3) behavior significantly correlated; Helping / Friendly, Dissatisfaction, and Admonishing, only the behavior Helping/Friendly which significantly correlated (at the .05 level) with students attitudes toward science subjects.

\section{CONCLUSION AND RECOMMENDATION}

Overall, it can be concluded that the Indonesian version Questionnaire of Teacher Interaction (QTI) is reliable $(\mathrm{aC}=$ 0.86 ) to be applied to the high school students in the Central Aceh Regency. It is also considered that the questionnaire can possibly be re-adjusting in order to be more suited to high school students.

The fact that students perceived their science teachers demonstrated more positive interpersonal behavior rather than the negative. From the positives, the teacher shows three behaviors in good level (2.5 to 3.4); namely Leadership (3.00 \pm 0.49$)$, Helping/Friendly $(3: 43 \pm 0.61)$, and 
Understanding (2.91 $\pm 0: 55)$. However, the students perceived their teachers fairly (1.89 \pm 0.77) express Responsibility/ Freedom to them. Oppositely, from the negatives, the teachers less showed Uncertainty, but fairly (1.5 to 2.4 ) showed satisfaction (Dissatisfaction-OS), patience (Admonishing), and Strictness. However, the behavior expected by students is higher than the behavior they perceived from their teacher in every QTI scale. This means that the students evidently are expecting better behavior from their science teachers at each of the scale

Regarding the correlation between Behavior interpersonal subject teachers of science and students' attitudes toward their subject, it can be concluded that of three (3) behavior significantly correlated; Helping / Friendly, Dissatisfaction, and Admonishing, only the behavior Helping/Friendly which significantly correlated (at the .05 level) with students attitudes toward science subjects.

Students in different location, ethnic, and culture might construct different perception on what ideal teacher they expect. This study, proposed to reemphasize the usefulness of this method for teachers taught specific subject to involve their understanding on their student rather than implementing their ideal education understanding with "closed eyes" in their classes. This method-for-reflection concept might provide an additional opinion on what happen in the certain learning environment the teacher should create. 


\section{REFERENCES}

Ben-Chaim, D., \& Zoller, U. (2001). Selfperceptions versus students' perceptions of teacher interpersonal style in college science and mathematics courses. Research in Science Education, 31(3), 437-454.

Brekelmans, M., Wubbels, T., \& Creton, H. A. (1990). A study of student perceptions of physics teacher behaviour. Journal of Research in Science Teaching, 27(4), 335-350.

Brok, P. D., Fisher, D., \& Scott, R. (2005). The importance of teacher interpersonal behaviour for student attitudes in Brunei primary science classes. International Journal of Science Education, 27 (7), 765-779.

Brok, P. Den., Brekelmans, M., \& Wubbels, T. (2004). Interpersonal teacher behaviour and student outcomes. Journal of School Effectiveness and School Improvement, 15 (3/4), 407-442.

Brok, P. D., \& Levy, J. (2006). Teacherstudent relationships in multicultural classes: reviewing the past, preparing the future. International Journal of Educational Research. Presented paper at the annual meeting of the American Educational Research Association, San

Francisco, 7-11 April 2006.

Brown, J. D. (2002). The Cronbach alpha reliability estimate. Shiken: $J A L T$ Testing \& Evaluation SIG Newsletter. (pp.17-18).

Evans, H. (1998). A study on students' cultural background and teacherstudent interpersonal behaviour in Secondary Science classrooms in
Australia. Unpublished doctoral dissertation. Perth: Curtin University of Technology.

Fisher, D. L, S. W., Goh \& Rickards, T. W. J. (1996). Perceptions of Interpersonal Teacher Behaviour In Secondary Science Classrooms: A Cross-National Study. Australian Association for Research in Education. Paper Presented at the Join ERA/AARE Conference, Singapore. Pg: 1-11.

Fraser, B. J. (1998). Science Learning Environtments: Assessment, Effect and Determinant. International Handbook of Science Education. Kluwer Academic Publisher: England. Pg. 527-564.

---. (2002). Learning Environment Research: Yesterday, Today, and Tomorrow. In: An International Perspective Studies in Learning Environment. Singapore: World Scientific Publishing:

George, D., \& Mallery, P. (2003). SPSS for Windows step by step: A simple guide and reference. 11.0 update (4th ed.). Boston: Allyn \& Bacon.

Goh, S. C. (1994). Introducing a model of interpersonal teacher behavior. Teaching and Learning, 15(1), 3040. Retrived from https://repository.nie.edu.sg.

Goh, S. C \& Fraser, B. J. (1998). Teacher interpersonal behaviour, classroom environment and student outcomes in primary mathematics classes in Singapore. Learning Environments Research, 1(2), 199229.

ICIRE. the International Conference on Interpersonal Relationships in Education. Retrived from http://www.icire.net. 
Khalili, K.Y. (2006). A Crosscultural Validation of a Test of Science Related Attitudes. Journal of Research in Science Teaching. 24. (2), 127-136.

Lee, S. S. U., Fraser, B. J., \& Fisher, D. L. (2003). Teacher-student interactions in Korean high school science classrooms. International Journal of Science and Mathematics Education, 1, 67-85.

Martin, A. (2014). Interpersonal Relationships and Students' Academic and Non-academic Development: What Outcomes Peers, Parents, and Teachers Do and Do Not Impact. Advances in Learning Environments Research, 5, 9-18.

Maulana R., Opdenakker, M. C., Brokb, P. D., \& Bosker, R. (2010), TeacherStudent Interpersonal Relationships In Indonesia: Profiles And Importance To Student Motivation. Asia Pacific Journal of Education, 31(1), 33-49.

---. (2012). Teacher-student interpersonal relationships in Indonesian lower secondary education: Teacher and student perceptions. Learning Environment Res. 15: 251-271.

Soerjaningsih, W. (2001). TeacherStudent Interpersonal Behaviour and Student Outcomes Among University Students in Indonesia. Paper Presented at the Australian Association for Research in Education (AARE), Fremantle, December 2, 2001.
Wahyudi \& Treagust, D. F. (2006). Science Education in Indonesia: A Classroom Learning Environment Perspective. In D. L. Fisher \& M. S. Khine (Eds.), Contemporary approaches to research on learning environments. Singapore: World Scientific.

--. (2004). Learning Environment and Students' Outcomes In Science Classes In Indonesian Lower Secondary Schools. Journal of Science and Mathematics education in South East Asia, 27(1), 139-165.

Wahyudi (2010). Teacher-Students Interaction and Classroom Learning Environments: Its Impacts on Students' Attitude Towards Science and Math Classes. International Journal of Education. 33(1), 41-52.

Wardana, A (2007). Menggunakan SPSS dalam Penelitian Sosial: Disadur dari SPSS Survival Manual karangan Julie Pallant. Yogyakarta: Universitas Negeri Yogyakarta.

Wells C. S and Wollack, J. A. (2003), An Instructor's Guide to Understanding Test Reliability. Journal of Testing \& Evaluation Services publication, University of Wisconsin. 4, 2003

Zandvliet, D., Brok, P. D., T. Mainhard, \& Van, T. J. (2014). The Theory and Practice of Interpersonal Relationships in Education, 
Advances in Learning

Environments Research, 5, 1. 